\title{
The historiography of the Romanesque period architecture in Portugal (1870-2010)
}

PhD in History of Art presented to the Faculdade de Letras of Oporto University, August 2010. Orientation of Professora Doutora Lúcia Maria Cardoso Rosas.

\section{Maria Leonor Botelho}

\section{(2) OpenEdition}

12 Journals

\section{Electronic version}

URL: http://journals.openedition.org/medievalista/204

DOI: 10.4000/medievalista.204

ISSN: 1646-740X

\section{Publisher}

Instituto de Estudos Medievais - FCSH-UNL

\section{Electronic reference}

Maria Leonor Botelho, «The historiography of the Romanesque period architecture in Portugal (1870-2010) », Medievalista [Online], 10 | 2011, Online since 01 July 2011, connection on 22 September 2020. URL : http://journals.openedition.org/medievalista/204 ; DOI : https://doi.org/ 10.4000/medievalista.204

\section{(c) (1) (8)}

Mediavalista está licenciado com uma Licença Creative Commons - Atribuição-NãoComercial 4.0 Internacional 
Título: Apresentação de Tese

A luz da grisalha. Arte, Liturgia e História no Livro de Horas dito de D. Leonor-Il165 da BNP.

Tese de Mestrado em História da Arte Medieval apresentada à Faculdade de Ciências Sociais e Humanas da Universidade Nova de Lisboa, Setembro 2010. Orientação da Professora Doutora Maria Adelaide Miranda

Autor(es): Delmira Espada

Enquadramento Institucional: Membro do Instituto de Estudos Medievais Contacto: delmiraespada@gmail.com

Fonte: Medievalista [Em linha]. №10, (Julho 2011). Direc. José Mattoso. Lisboa: IEM.

Disponível em: http://www2.fcsh.unl.pt/iem/medievalista/

ISSN: $1646-740 \mathrm{X}$ 


\section{Apresentação de Tese}

A luz da grisalha. Arte, Liturgia e História no Livro de Horas dito de D. LeonorIl165 da BNP.

Tese de Mestrado em História da Arte Medieval apresentada à Faculdade de Ciências

Sociais e Humanas da Universidade Nova de Lisboa, Setembro 2010. Orientação da

Professora Doutora Maria Adelaide Miranda

\section{Delmira Espada}
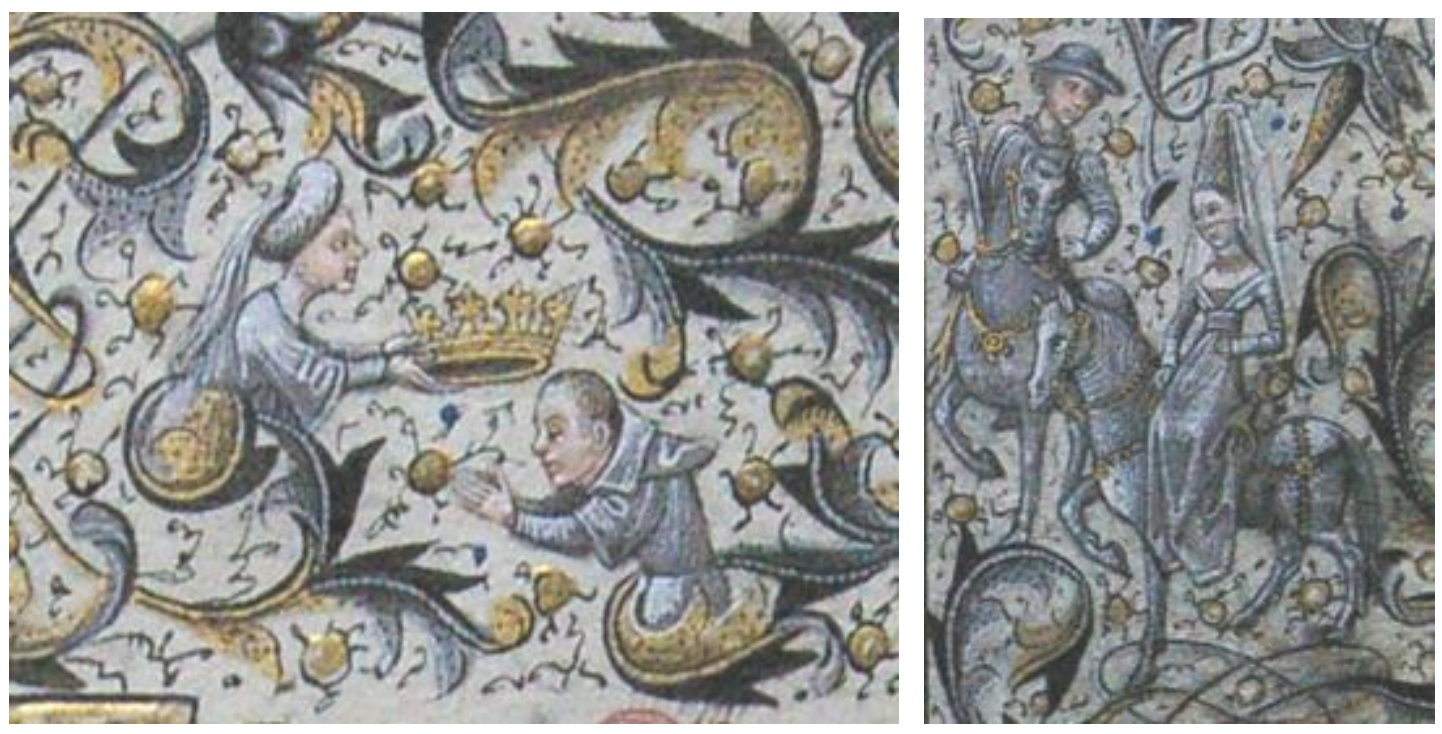

BNP, IL165, f1. 62

The dissertation entitled "The light of grisaille. Art, history and liturgy in the Book of Hours ascribed to Queen Eleanor of Portugal - IL165 from BNP" refers to one of the most remarkable manuscripts of the fifteenth century in Portugal. It is the focus of our investigation, involving the historical, artistic and liturgical aspects of its production. The volume is divided into eight chapters. In terms of methodology we started by raising the state of the art and develop a short approach to the figure of Eleanor of 
Portugal, in her historical time, establishing possible routes that could have led the manuscript to the Queen. From the direct observation of the codex resulted its codicological description and the precise definition of its structure. This was essential for the transcription of the text, which helped us to understand the sections that comprise it and its relationship with the thumbnails and liturgical aspects. The demand for models and iconographic analysis, two key steps in this type of work, focused on the marginal figurations and full-page miniatures, having been made inside and outside the corpus. The work only became complete with the framing of the codex in the context of the illuminator work and the study of illuminated manuscripts in the late Middle Ages, particularly the way it explored the grisaille.

From all these subjects, we chose to expose a short presentation of the manuscript, a comparative analysis of its miniatures, the iconographic analysis of marginal figurations present in the Office of the Virgin, and finally the possible reconstitution of the route of the manuscript.

Commonly known as the Book of Hours of Eleanor of Portugal, dates from the third quarter of the fifteenth century and was illuminated in gold and grisaille, with occasional applications of colour. Illuminators appropriated this expressive pathway, exploring it, mainly for its potential of aesthetic innovation. It was widely accepted within the fourteenth century French court, meeting new impetus in the fifteenth century Flanders, where it was applied in a very creative way. Fully lighted in grisaille, our manuscript is presented as one of the best achieved examples of the whole corpus of its author, the Flemish Willem Vrelant, a notable artist coming from Utrecht, who developed the most significant part of his career in Bruges. The codex has a good state of preservation, though around ten full-page miniatures are missing. It is a manuscript of exception, of high plastic quality, at the level of the best produced in Flanders, suggesting, from the start, a commissioner of great prestige. It comprises 14 sections, highlighting the absence of the Hours of the Holy Spirit, the O Intemerata and the Suffrages. Formally, the beginning of each section included the introduction of two decorated folios, with well developed borders. The rhythm of the text is marked by the introduction of the red lines, initial ornamented and enhanced with watery yellow caps. Currently, it includes six full-page miniatures in loose folio, executed on thicker parchment. 

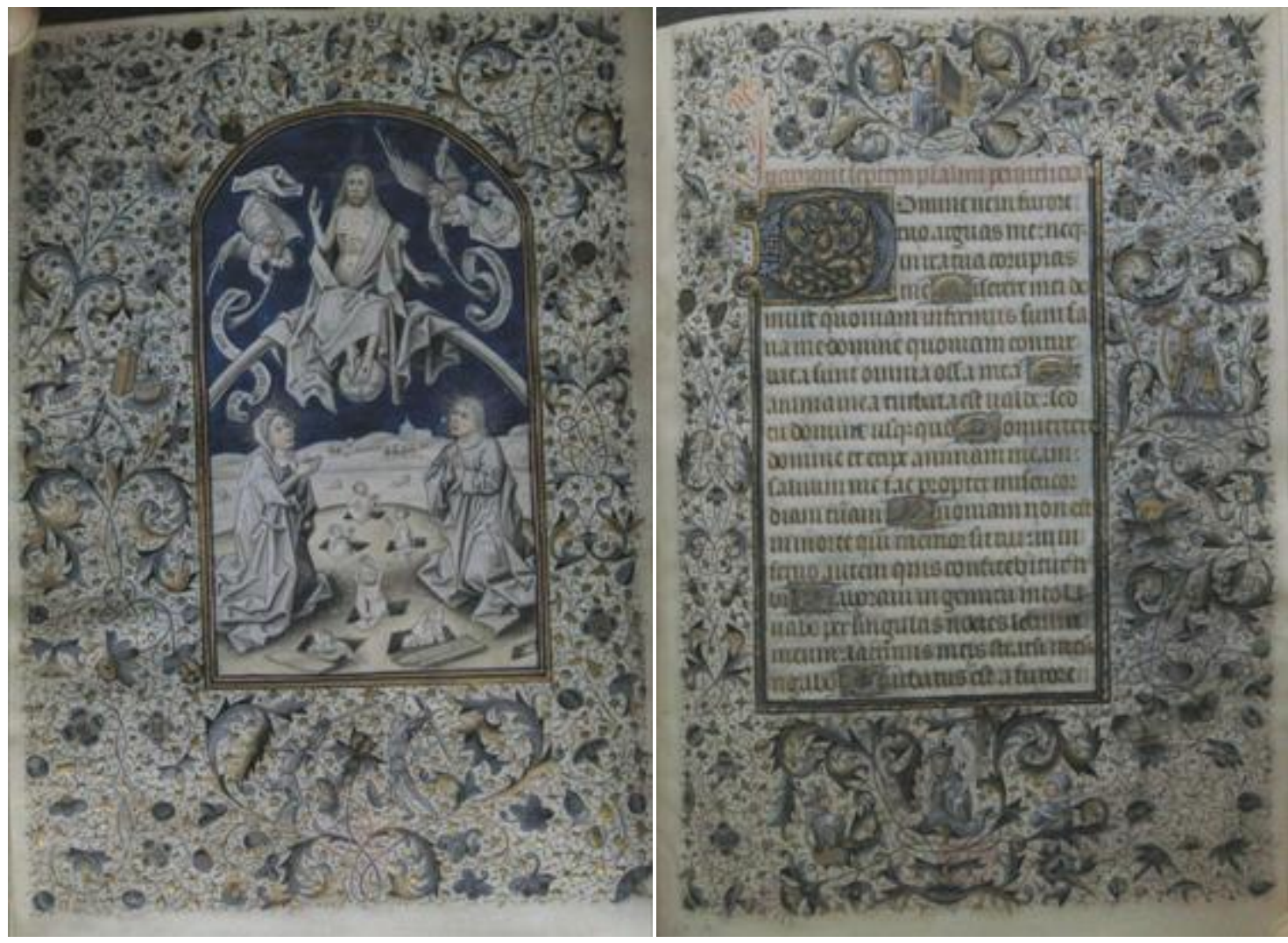

BNP, IL165, fls. 99v and 100

The search for models, led us also to the allocation of the "Cofre 13 of Coimbra" if not to Vrelant at least to his inner circle, since we have detected many similarities between this codex and another one from a private collection, which Bousmanne has included in the corpus of Vrelant. Not being a work of excellence (like IL 165), is yet at the level of other tasks.

Moreover, comparative analysis of the miniatures in and out of that corpus, coupled with the study of grisaille production, led us to MS 854 of the Pierpont Morgan Library, which suggests a link between Vrelant and Juan de Carrion allowing, on the basis of this relationship, to define a possible route of the codex into the hands of Queen Eleanor. This miniaturist is securely documented in the Castilian region of Avila from 1470, for his cooperation in the Books of the Cathedral Choir. Linette Bosch claims that his studio was active between 1465 and 1480, which coincides with the execution of our manuscript. According to her, he had been initiated for the infant Afonso and concluded, since after his death, to his sister Isabella the Catholic, which explains the 
formal proximity between some thumbnails of two codices, especially the Visitation and the Annunciation to the Shepherds.

Although the provision of a full-page illuminations to Vrelant is a consensus among various authors, no author has expressed his opinion in relation to marginal figurations. From what we have seen, we believe we have assembled the necessary arguments to assign them to the same illuminator. Although the scale of representation is rather limited, the design is strong, and expressive faces and poses incorporate a narrative character.

According to the reading we propose, the nuclei of figuration present at the margins of the Office of the Virgin - the Book of Hours most important part - narrate, in essence, a secular history of a biographical nature, whose relationship with the texts is only done indirectly through the parallels with the biblical narratives of the thumbnails. A joint reading of these nuclei will present the story of the king of France, Charles VII, with special focus on the intervention of Joan of Arc, in the episode that reversed the outcome of the Hundred Years War and ended the conflict.

Thus, the figurations of the Mass of the Blessed Virgin Mary (which precedes the Office) and at Matins present what we believe to be the first year rule of Charles VII. Several images of this monarch are known, but the one which is relevant here is the miniature that accompanies the Gospel according to St. Matthew in the Book of Hours of Étienne Chevalier, where the king is represented himself and his children (Charles and Louis XI of France), in place of the Magi. This miniature interests us in several ways: first, is a contemporary realization of the manuscript under review, and second, the costume of Charles VII coincides with the marginal figurations of our manuscript and, finally, the fact that the king is represented within a biblical narrative, even taking the place of a character, finds many parallels with the iconographical reading we have proposed.

Another of the representations that interests us to evoke is a drawing, dating from the sixteenth century, that Francois Avril has made known in 2003. This drawing inserts a representation of Charles VII, formally similar to that previously mentioned, accompanied by brief description that tells the intervention of Joan of Arc in regaining independence from France. 
Based on this scenario, we believe that the scenes of courtship and courtly life, respectively, in folios 33 and 40, can portray the dauphin Charles and his wife, Mary of Anjou. Not being, of course, faithful portraits, they reproduce typified figurations of a certain social status, which in the specific context of this codex, can be identified with actual figures.

Lauds contains scenes of fighting between supporters of the French cause (Armagnac) and the British, who the first sought to expel from its territory. The scene at the lower margin (folio 53v) was essential to identify the subject. The horn on the horse's head (an allusion certainly to the unicorn) and the female presence that the picture transmits, were determinant in the identification. Joan of Arc appears then fighting the enemies, in what probably was his first great divine mission: the liberation of the square of Orleans, which would definitely mark the turning of the Hundred Years War, or the fights she had on the way to Chinon, where she was received by the king in 1429 .

Moreover, the joint analysis of two folios (53v and 54) suggests a parallel between the biblical story of the miniature, and the historical episode represented in the coeval marginal figuration. It is thus stateda moment of hope for humanity: the announcement of the coming of the Messiah, the presence of the expectant belly, and the salvation of the French crown by divine intervention, embodied in the figure of Pucelle.
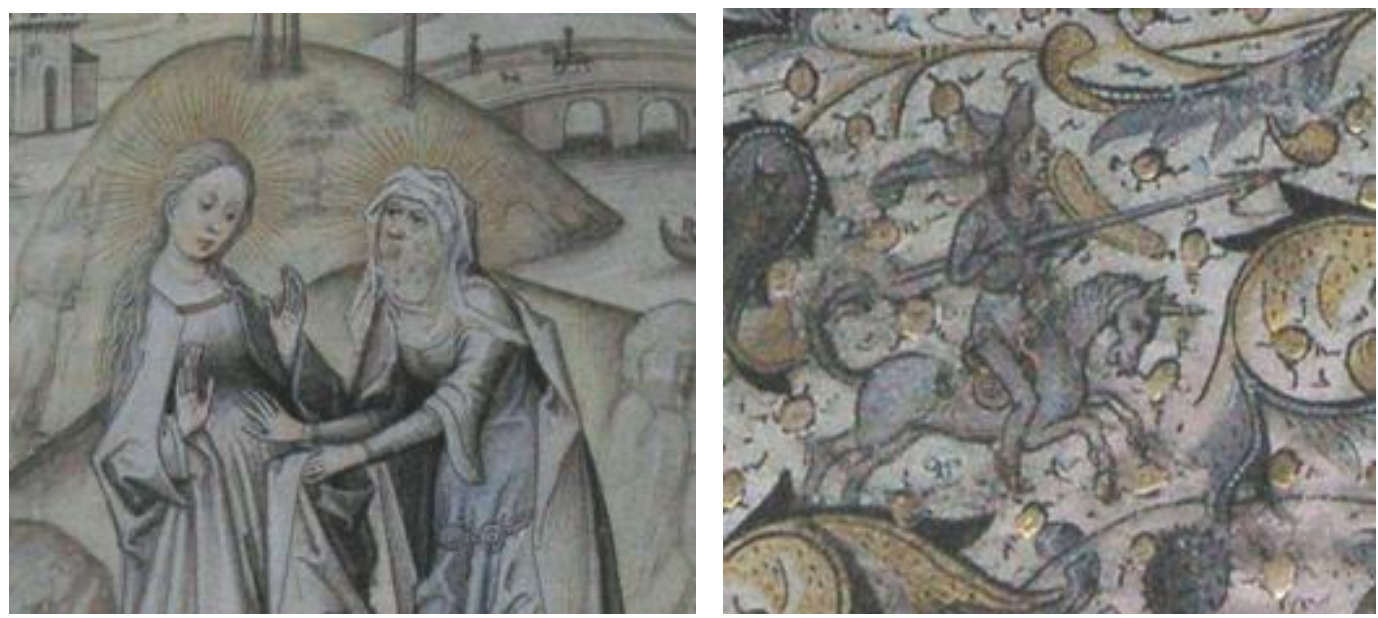

BNP, IL165, fl. 53v

Medievalista online № 10| Julho - Dezembro 2011 ๑ IEM - Instituto de Estudos Medievais 6 www2.fcsh.unl.pt/iem/medievalista 
The margin of folio 62 prefigure the great turning point in the life of the future Charles VII and the achievement of the mission of Joan of Arc: the consecration of the Dauphin in Rheims, which definitely legitimized his succession to the throne of France. The scene that unfolds in the lower margins is unambiguous, representing a warrior woman who comes from a lower social class. During this period, apart from Joan of Arc, what other women in these circumstances would appear in Book of Hours? Moreover, the fact that, in the margin upside in the same folio, a king appears to be crowned. What other king but Charles VII was crowned with the help of a warrior woman? The little scene at the beginning of Prima, is certainly the solemn consecration of the monarch in Reims, which occurred on July 17, 1429.

Harder to explain is why the coronation is made by a female figure. If, at first, we doubt it is the case of Joan of Arc, after some reflection we were forced to conclude that this is the most accurate reading. No other woman would justify her presence within this representation. One the contrary, the figure of Joan of Arc is of great significance: she was responsible for the ascension to the throne of the monarch and this was her divine mission, to crown the king in God's name.
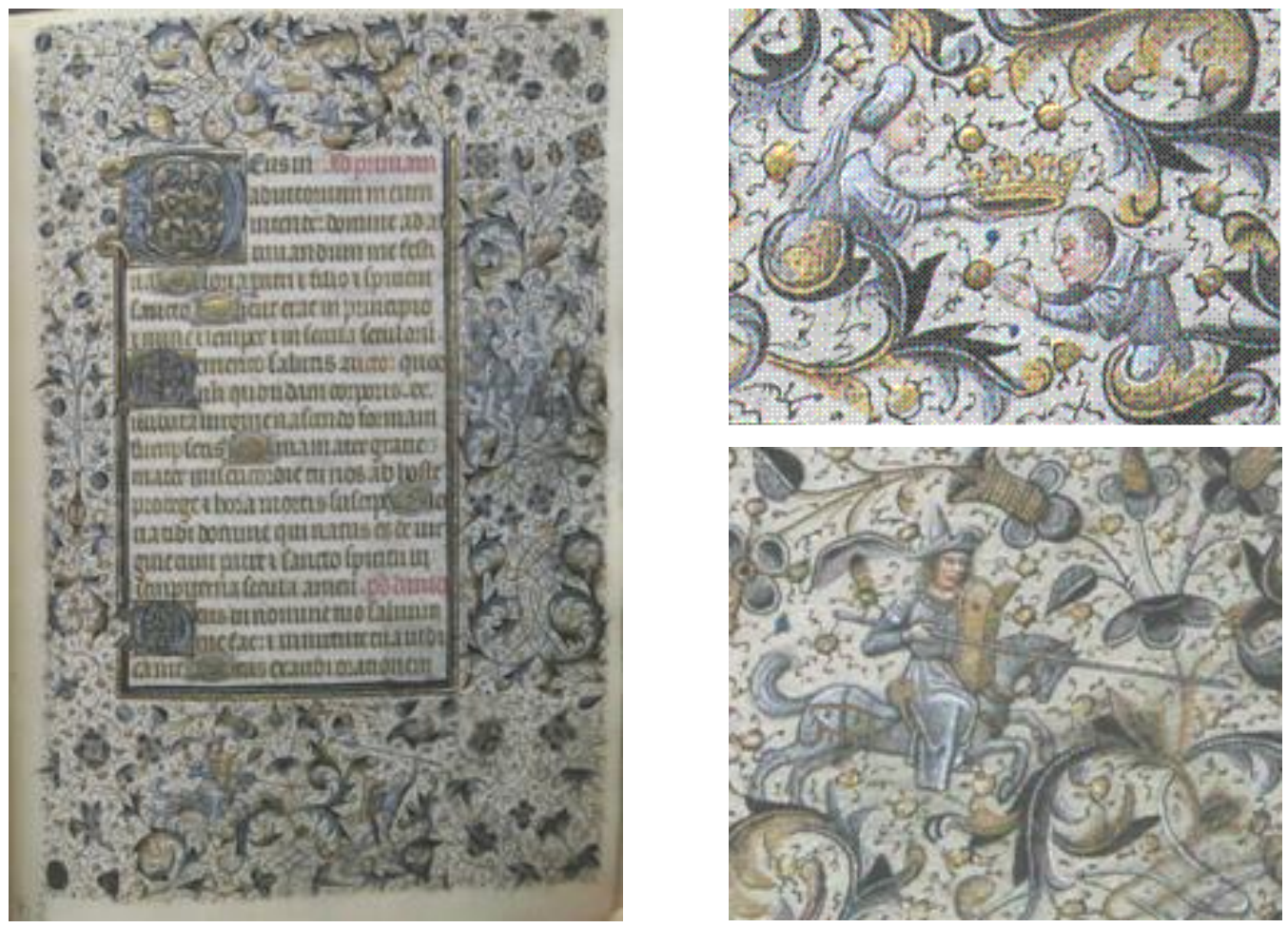

BNP, IL165, fl. 62 
On Terce, figurations continue the struggle for the expulsion of the British, at the same time announcing the celebration of the coronation of Charles VII, symbolically charged, by this anthropomorphic figure, half man half beast. Contrary to what occurs on folio 3 , the bust of this figure is clearly male, coating the dignity of a statesman. The animal itself that supports the bust (a kind of wolf) implies an uplifting attitude, having the neck wrapped in a golden drapery. Situation is analogous to a Pentecost on folio 195v of the Book of Hours of John the Fearless, where, standing on the shore, are a lion and a fox, depicting the conflict between the Duke of Burgundy and Louis of Orleans, in which the latter (here represented by the fox) was assassinated at the behest of the former.

There is also the fact that the figure is crowned. This symbol of the new monarch shows him as a confident leader, taking charge of the command of the reconquest of French territory. Again, the illuminator, on its own initiative or under patronage instructions, sought the parallels between biblical history and contemporary events: the announcement of the birth of Christ, who seeks the salvation of Men and the legitimation of the dauphin who prepares the release of France from English rule.
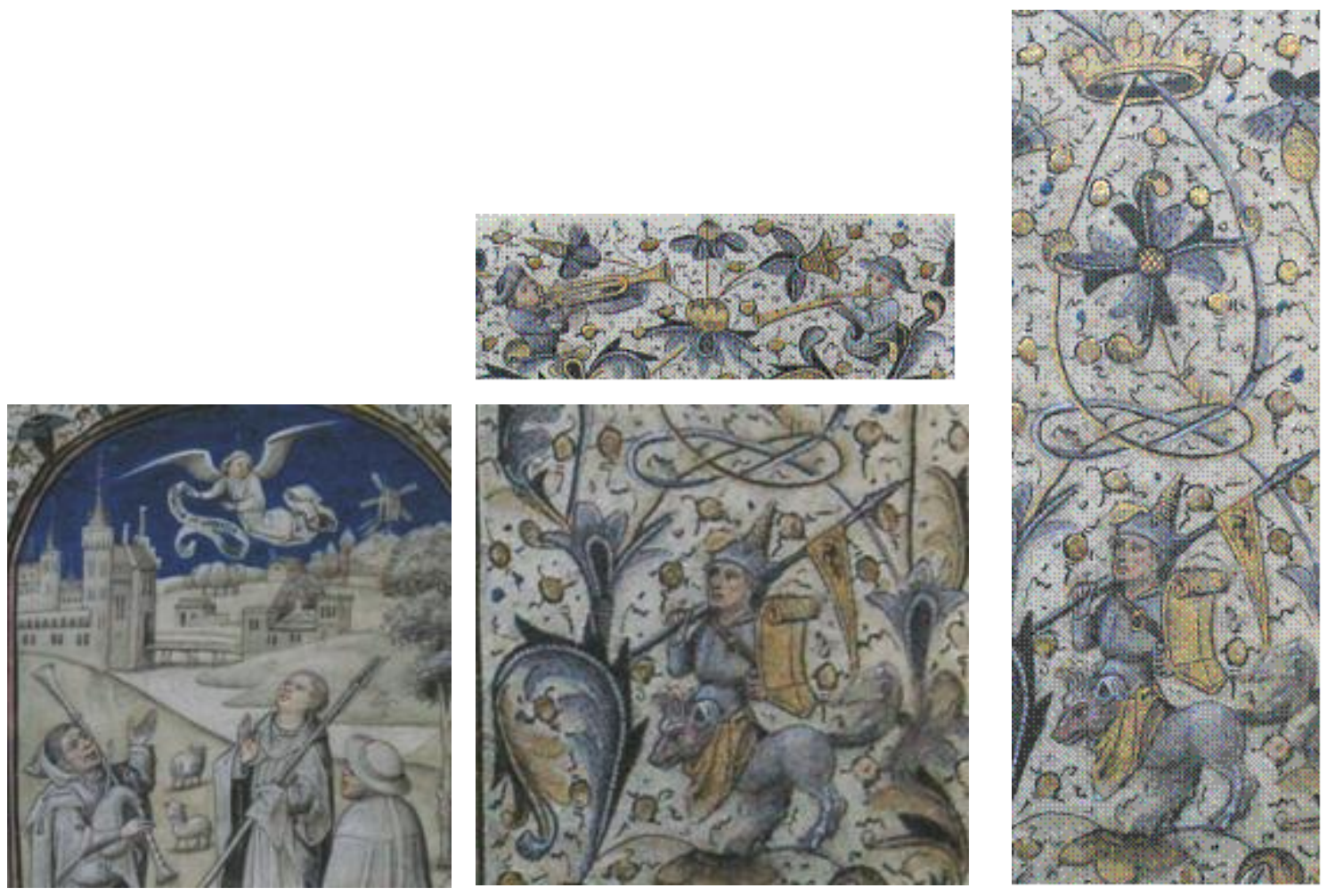

BNP, IL165, fls. 65v and 66

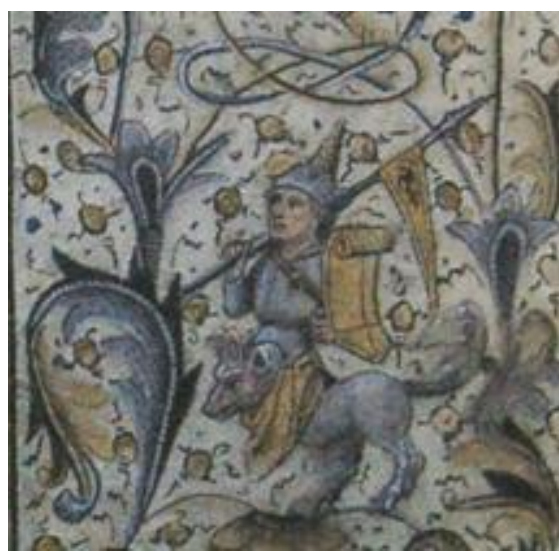

Medievalísta online $\mathrm{N}^{\circ} 10 \mid$ Julho - Dezembro 2011 @ IEM - Instituto de Estudos Medievais 8 www2.fcsh.unl.pt/iem/medievalista 
At Sext, the marginal figurations give continuity to the narrative that we have been presenting, converging on the interpretation of the scenes as the tournament commemorating the recent coronation of the monarch, in Reims. In the nuclei of None, we stress the lower margin of folio $72 \mathrm{v}$. Apparently only a hunting scene, this representation can be understood as an allusion to the martyrdom of Joan of Arc, and there is, again, the symbolic link between the two narratives: the first blood Christ shed for mankind, through circumcision (thumb) and the sacrifice of the Pucelle, here symbolized by the dove, who is martyred in the name of its divine mission (figurations marginal).
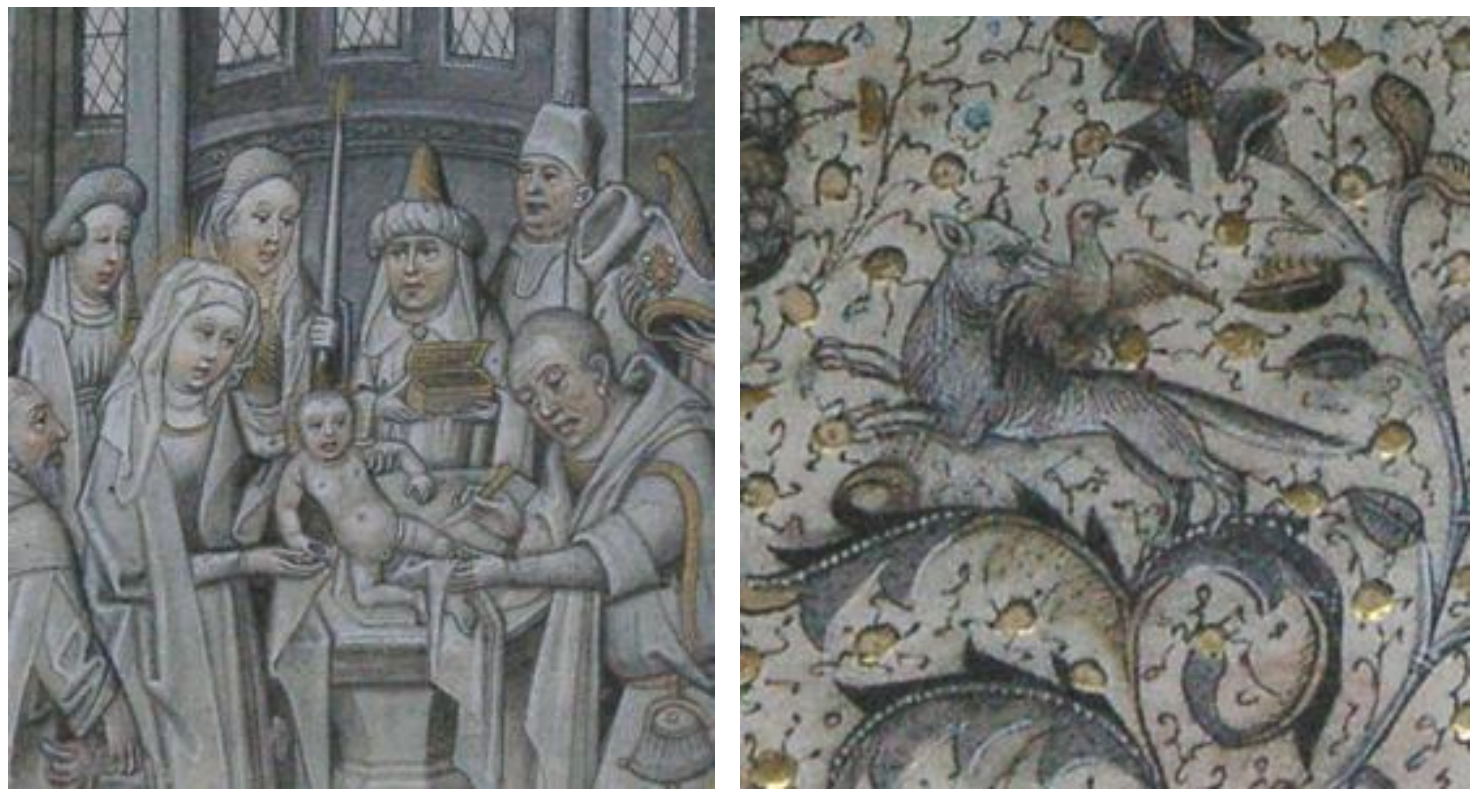

BNP, IL165, fl. 72v

Given the above, we thought that this manuscript has not been made specifically for Eleanor of Portugal, having come to her hands indirectly, possibly through a gift or by her own purchase.

Several authors suggest that Vrelant has searched for patrons in France, although there is no documentation that proves it. The narrative that we found on the margins of the Office of the Virgin reinforces, in our view, this possibility. Evaluating his course, we note that there are two instances in which the illuminator may have gone to France: the period between his departure of Utrecht and the installation in Bruges (1449-1451/54),

Medievalísta online $\mathrm{N}^{\circ}$ 10| Julho - Dezembro 2011 @ IEM - Instituto de Estudos Medievais 9 www2.fcsh.unl.pt/iem/medievalista 
or one that seems more feasible, between May 6, 1456 and June 28, 1459, in other words, during the period of time that he does not pay its contribution to the guild of St. John Evangelist of Bruges. Moreover, it is therefore pertinent to stress, that this interval (1456-59) coincides exactly with the annulment of the sentence which condemned Joan of Arc in 1431. By order of Charles VII, the case was reviewed and ordered its cancellation precisely in the year 1456.

Two other factors make us think that during the time that Vrelant suspended payment of his contributions he could have been in the Iberian Peninsula. Firstly, the said Book of Hours of Isabel the Catholic (Madrid, Biblioteca del Palacio, sn), allocated to the illuminator, was first owned by the Queen of Navarre and Aragon, Joan Enriquez. The latest annexation, in 1458, of the Crown of Aragon to Navarre which already had, puts it in an understandable predisposition to commission and sponsor artistic objects. The second clue that alerts us to the presence of Vrelant in the Peninsula follows, once again, from direct observation of our object of study and the similarities found between this codex and MS 854 of the Pierpont Morgan Library.

It seems to us therefore quite feasible that Vrelant has worked in the area of Navarra and Aragon, linked to the patronage of Queen Joanna Enriquez until 1459, when he may have returned to Bruges, leaving there the illuminated 165, maybe in possession of D. Ferdinand, son of that queen. When he marries Isabel the Catholic, in 1469, the manuscript will have escorted him to Castile where Juan de Carrion could have had contact with the codex.

Once you know Joanna the Mad, daughter of Isabella and Fernando, inherited the said Book of Hours of Isabella the Catholic, it seems plausible that the IL 165 has entered Portugal with one of his sisters, the Infanta Isabel, at the time of her marriages to Prince Afonso (1490) and later D. Manuel (1497) or with Infanta Mary, who married the sovereign in 1500 . 

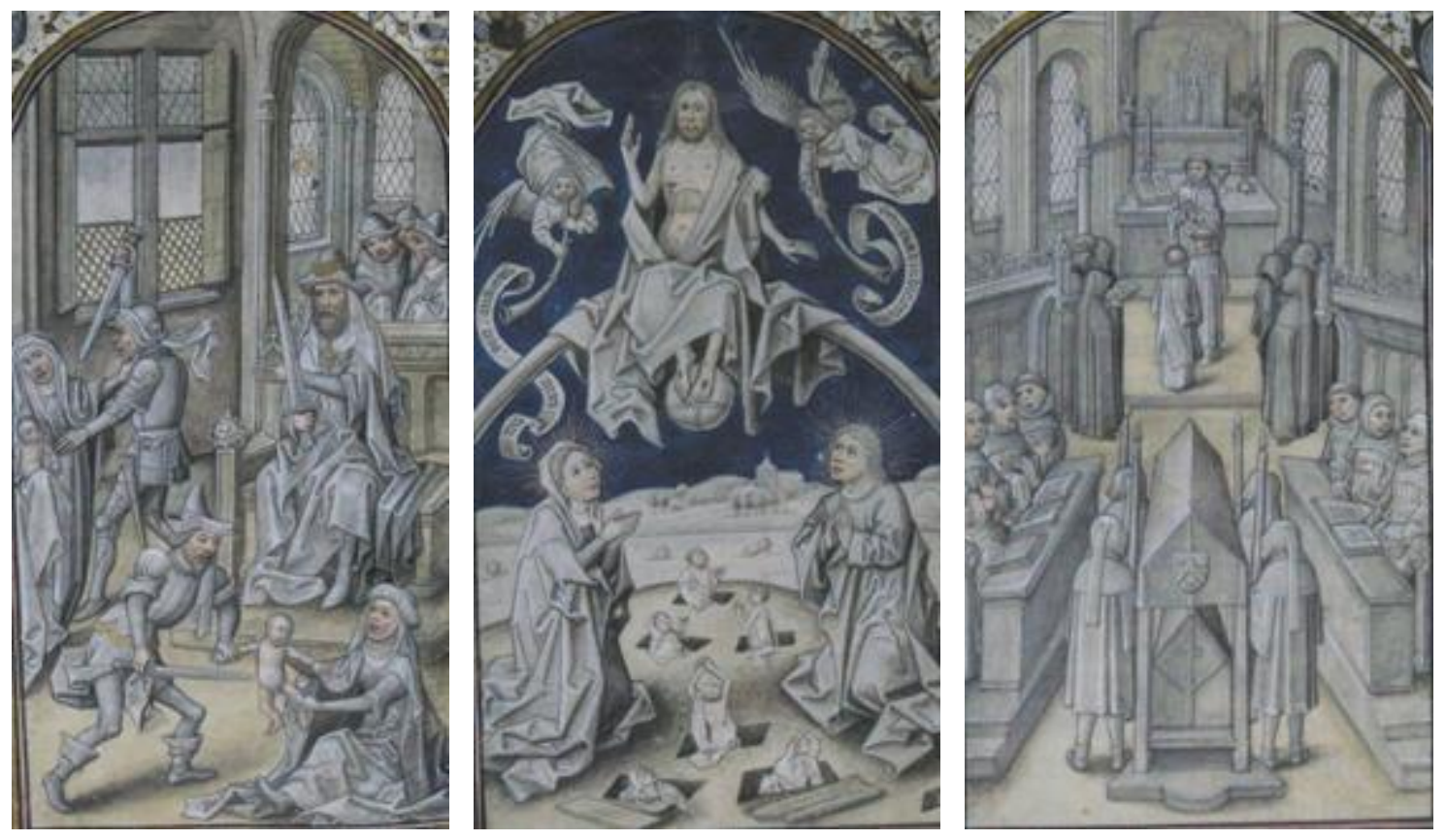

BNP, IL165, fls. 76v, 99v and 114v

\section{COMO CITAR ESTE ARTIGO}

\section{Referência electrónica:}

ESPADA Delmira - A luz da grisalha. Arte, Liturgia e História no Livro de Horas dito de D. Leonor - Il165 da BNP. Tese de Mestrado em História da Arte Medieval apresentada à Faculdade de Ciências Sociais e Humanas da Universidade Nova de Lisboa, Setembro 2010. Orientação da Professora Doutora Maria Adelaide Miranda. Medievalista [Em linha]. №10, (Julho de 2011). [Consultado dd.mm.aaaa]. Disponível em http://www2.fcsh.unl.pt/iem/medievalista/MEDIEVALISTA10lespada1009.html. ISSN 1646-740X. 
Apresentação de Tese - Delmira Espada

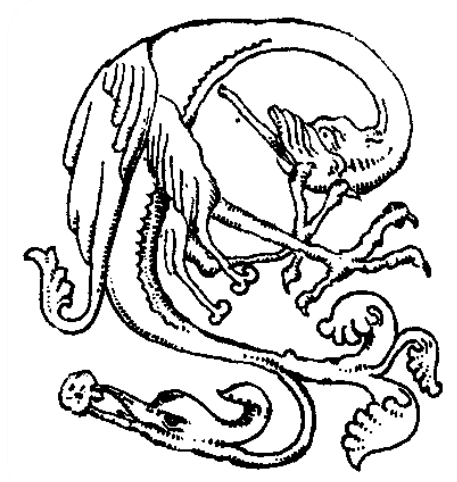

Medievalísta online № 10I Julho - Dezembro 2011 @ IEM - Instituto de Estudos Medievais 12 www2.fcsh.unl.pt/iem/medievalista 